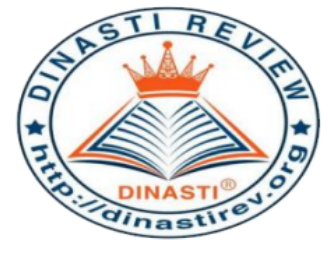

+62 878-9658-6407

087896586407

https://dinastirev.org/JIMT

editor@dinastirev.org

\title{
PENGARUH PENGGUNAAN TOTAL UANG TUNAI, AKTIVA TETAP, DAN KEWAJIBAN JANGKA PANJANG TERHADAP LABA BERSIH DI PT. ADHI KARYA TBK PERIODE 2007-2016
}

Susi Artati ${ }^{1}$

${ }^{1)}$ Dosen Fakultas Ekonomi Universitas Batanghari, Jambi, Indonesia

\begin{tabular}{|c|c|}
\hline $\begin{array}{c}\text { ARTICLE INFORMATION } \\
\text { Received: } 20 \text { April } 2020 \\
\text { Revised: } 26 \text { April } 2020 \\
\text { Issued: } 5 \text { Mei } 2020 \\
\text { Corresponding Author: } \\
\text { Susi Artati } \\
\text { E-mail: susiartati30@gmail.com }\end{array}$ & $\begin{array}{l}\text { Abstrak: Tujuan penelitian ini adalah untuk mengetahui } \\
\text { bagaimana pengaruh penggunaan total kas, aktiva tetap, } \\
\text { dan kewajiban jangka panjang terhadap laba bersih pada } \\
\text { PT. Adhi Karya Tbk secara simultan dan parsial. Objek } \\
\text { yang digunakan adalah PT. Adhi Karya Tbk telah } \\
\text { terdaftar di Bursa Efek Indonesia di mana sebuah } \\
\text { perusahaan konstruksi memimpin para menteri di } \\
\text { tenggara. Dalam penelitian ini, Penulis menggunakan } \\
\text { Data Sekunder. Statistik-nya untuk perhitungan penulis } \\
\text { menggunakan SPSS versi 22. Alat analisis yang } \\
\text { digunakan adalah Regresi Linier Berganda dan Koefisien } \\
\text { Determinasi. Berdasarkan hasil Analisis Regresi } \\
\text { Berganda menunjukkan persamaan Y = 68244.954+ } \\
\text { 0,29X1 - 0,79X2 + 0,167X3 + e dengan nilai uji F } \\
\text { 15,327. nilai uji t untuk total kas adalah 0,890, untuk } \\
\text { total aset tetap adalah (-0,995), sedangkan nilai uji t } \\
\text { untuk kewajiban jangka panjang adalah } 3,416 \text { dan nilai } \\
\text { R2 adalah 0,885. Kesimpulan dari penelitian ini } \\
\text { menunjukkan bahwa secara simultan total aktiva lancar, } \\
\text { aktiva tetap, dan kewajiban jangka panjang ada yang } \\
\text { secara signifikan mempengaruhi laba bersih. Sedangkan } \\
\text { hasil penelitian secara parsial menunjukkan bahwa total } \\
\text { uang tunai tidak memiliki pengaruh yang signifikan } \\
\text { terhadap laba bersih. Pada aktiva tetap secara parsial } \\
\text { tidak berpengaruh signifikan terhadap laba bersih. Jadi } \\
\text { dalam jangka panjang kewajiban secara parsial } \\
\text { berpengaruh signifikan terhadap laba bersih. } \\
\text { Kata Kunci: Total Uang Tunai, Aktiva Tetap, Dan } \\
\text { Kewajiban Jangka Panjang Terhadap Laba Bersih }\end{array}$ \\
\hline
\end{tabular}

\section{PENDAHULUAN}

Perkembangan dunia usaha dewasa ini semakin berkembang, maka persaingan antar perusahaan khususnya antar perusahaan yang sejenis akan semakin ketat. Tujuan utama dari perusahaan adalah untuk memperoleh laba yang optimal atau investasi yang ditanamkan 
dalam perusahaan untuk mempertahankan dan menjamin kelangsungan hidup perusahaan. Untuk menjaga kelangsungan hidup perusahaan dalam menghadapi persaingan yang ketat tersebut, maka diperlukan suatu penanganan dan pengelolaan sumber daya yang dilakukan oleh pihak manajemen dengan baik. Bagi pihak manajemen, selain untuk dapat mengkoordinasikan penggunaan seluruh sumber daya yang dimiliki oleh perusahaan secara efisien dan efektif, juga dituntut untuk dapat menghasilkan keputusan-keputusan yang menunjang terhadap percapaian tujuan perusahaan dimasa yang akan datang.

Salah satu sumber informasi dari pihak eksternal dalam menilai kinerja perusahaan adalah laporan keuangan. Laporan keuangan merupakan sebuah informasi yang mencatat, merangkum segala aktivitas perusahaan dan digunakan untuk melaporkan keadaan dan posisi perusahaan pada pihak yang berkepentingan, terutama padaa pihak kreditur, investor, dan manajemen perusahaan itu sendiri. Untuk menggali lebih banyak lagi informasi yang terkandung dalam sebuag laporan keuangan diperlukan suatu analisis laporan keuangan. Apabila informasi disajikan dengan benar, informasi berguna dalam pengambilan keputusan dan mengetahui kinerja perusahaan.

Kas yang baik merupakan kunci keberlangsungan usaha. Tidak dapat dipungkiri hampir seluruh aktivitas perusahaan dilakukan dengan menggunakan kas. Arus kas sangat penting bagi perusahaan apapun. Tanpa arus kas, bisnis akan berhenti berfungsi. Dengan kata lain, setiap aktivitas operasional sangat bergantung pada kondisi arus kas. Dengan demikian pula untuk penggunaan kas yang tidak terkontrol akan mengakibatkan kas terkuras habis dan otomatis semua kegiatan operasional akan terganggu.

Penyusutan merupakan proses dimana harga perolehan aktiva tetap menjadi biaya selama masa manfaat. Aktiva tetap akan terus disusutkan tiap periode sampai habis masa manfaatnya. Aktiva tetap yang telah habis masa manfaatnya, harus dilakukan penggantian aktiva tetap yang baru agar kegiatan operasional perusahaan dapat berjalan dengan baik. Penggunaan aktiva tetap sesudah umur ekonomisnya habis yang disebabkan oleh ketidakmampuan perusahaan untuk membeli aktiva yang baru.Untuk mencapai tujuan tersebut, diperlukan manajamen yang dapat memadukan dan mengelola sumber-sumber daya yang dimiliki oleh perusahaan tersebut secara efektif dan efisien. Dalam menjalankan operasionalnya demi mencapai tujuan-tujuannya, perusahaan memerlukan dana yang bisa berasal dari luar perusahaan dan dari dalam perusahaan.

Aktiva tetap merupakan unsur yang sangat vital bagi suatu perusahaan artinya dengan adanya aktiva tetap didalam suatu perusahaan maka salah satu tujuan dari perusahaan yaitu profitabilitas perusahaan akan dapat tercapai. Jika kekurangan asset untuk mengembangkan produk dan jasa disuatu perusahaan, sedangkan permintaan semakin besar, maka perusahaan akan kehilangan konsumen. Tetapi terlalu banyak asset yang dimiliki akan mengakibatkan idle fixed asset (aktiva tetap yang menganggur) dimana aktiva tetap yang dimiliki tidak dapat digunakan secara optimal.

PT. Adhi Karya Tbk yang bergerak dibidang kontruksi merupakan perusahaan yang mempunyai total aktiva lancar,aktiva tetap, hutang dan modal yang cukup besar dan begitu juga membutuhkan biaya pemeliharaan yang besar juga. PT. Adhi Karya Tbk melakukan kegiatan usaha untuk menggunakan aktivadan modal yang ada dalam perusahaan secara efektif dan efisien.Oleh karena itu, manajemen PT.Adhi Karya Tbk melakukan perawatan yang sangat maksimal di perusahaan agar tujuan dari perusahaan dapat tercapai yaitu laba 
atau profit yang maksimal. Keberhasilan suatu perusahaan bukan hanya dilihat dari besarnya laba yang dimaksud. Adapun perkembangan rata-rata total kas dan aktiva tetap perusahaan PT. Adhi Karya Tbk selama periode 2007-2016 dapat dilihat pada tabel berikut:

Tabel 1: Perkembangan Total Kas dan Aktiva Tetap PT. Adhi Karya Tbk Periode 2007-2016 (Dalam Jutaan Rupiah)

\begin{tabular}{|c|r|r|r|r|}
\hline Tahun & Total Kas (Rp) & $\begin{array}{c}\text { Perkem } \\
\text { bangan } \\
(\mathbf{\%})\end{array}$ & Aktiva Tetap (Rp) & $\begin{array}{c}\text { Perkem } \\
\text { bangan } \\
(\%)\end{array}$ \\
\hline 2007 & 784.297 .751 .668 & - & 147.232 .941 .546 & - \\
\hline 2008 & 364.904 .002 .740 & $(53,47)$ & 166.809 .583 .460 & 13,30 \\
\hline 2009 & 306.902 .360 .957 & $(15,90)$ & 246.434 .530 .456 & 47,73 \\
\hline 2010 & 242.117 .620 .949 & $(21,11)$ & 186.401 .376 .095 & $(24,36)$ \\
\hline 2011 & 552.203 .272 .822 & 128,07 & 220.861 .285 .831 & 18,49 \\
\hline 2012 & 948.845 .841 .632 & 71,83 & 187.437 .135 .676 & $(15,13)$ \\
\hline 2013 & 1.939 .959 .892 .639 & 104,45 & 271.256 .911 .163 & 44,72 \\
\hline 2014 & 811.411 .723 .393 & $(58,17)$ & 496.095 .844 .221 & 82,89 \\
\hline 2015 & 4.317 .347 .903 .384 & 432,08 & 1.099 .426 .730 .019 & 121,62 \\
\hline 2016 & 3.364 .910 .489 .288 & $(22,06)$ & 1.459 .815 .811 .733 & 32,78 \\
\hline Total & $\mathbf{1 3 . 6 3 2 . 9 0 0 . 8 5 9 . 4 7 2}$ & $\mathbf{5 6 5 , 7 2}$ & $\mathbf{4 . 4 8 1 . 7 7 2 . 1 5 0 . 2 0 0}$ & $\mathbf{3 2 2 , 0 3}$ \\
\hline Rata-rata & $\mathbf{1 . 3 6 3 . 2 9 0 . 0 8 5 . 9 4 7 , 2}$ & $\mathbf{5 6 , 5 7}$ & $\mathbf{4 4 8 . 1 7 7 . 2 1 5 . 0 2 0}$ & $\mathbf{3 2 , 2 0}$ \\
\hline Sumber: Bursa Efek Indonesia Tahun 2007-2016 & \\
\hline
\end{tabular}

Berdasarkan Tabel 1 diatas diketahui bahwa perkembangan dari total kas pada PT. Adhi Karya Tbk selama 10 tahun terakhir mengalami fluktuasi meningkat dan menurun, dimana perkembangan total kas mengalami penurunan pada tahun 2014 sebesar $(58,17 \%)$ dan mengalami perkembangan yang meningkat paling tinggi berada pada tahun 2015 sebesar $432,08 \%$, dan dengan rata-rata perkembangan sebesar 56,57\%. Sedangkan perkembangan pada aktiva tetap juga mengalami fluktuasi dan pada tahun 2010 mengalami penurunan sebesar (24.,36\%) dan yang tertinggi pada tahun 2015 sebesar 121,62\%.

Tabel 2: Perkembangan Hutang Jangka Panjang dan Laba Bersih PT. Adhi Karya Tbk Periode 2007-2016 (Dalam Jutaan Rupiah) 


\begin{tabular}{|c|r|r|r|r|}
\hline Tahun & $\begin{array}{c}\text { Hutang Jangka } \\
\text { Panjang (Rp) }\end{array}$ & $\begin{array}{c}\text { Perkem } \\
\text { bangan } \\
(\mathbf{\%})\end{array}$ & Laba Bersih (Rp) & $\begin{array}{c}\text { Perkem } \\
\text { bangan } \\
(\mathbf{\%})\end{array}$ \\
\hline 2007 & 519.267 .945 .874 & - & 111.601 .403 .512 & - \\
\hline 2008 & 562.418 .088 .475 & 8,31 & 81.482 .495 .008 & $(26,99)$ \\
\hline 2009 & 557.483 .397 .383 & $(0,88)$ & 165.529 .733 .252 & 103,15 \\
\hline 2010 & 609.238 .056 .719 & 9,28 & 189.483 .638 .611 & 14,47 \\
\hline 2011 & 247.098 .000 .816 & $(59,44)$ & 182.692 .722 .038 & $(3,58)$ \\
\hline 2012 & 838.580 .545 .389 & 239,37 & 213.317 .532 .467 & 16,76 \\
\hline 2013 & 1.630 .841 .824 .515 & 94,48 & 408.437 .913 .454 & 91,47 \\
\hline 2014 & 1.637 .634 .722 .608 & 0,42 & 326.656 .560 .598 & $(20,02)$ \\
\hline 2015 & 2.184 .469 .703 .709 & 33,39 & 465.025 .548 .006 & 42,36 \\
\hline 2016 & 1.608 .286 .449 .267 & $(26,38)$ & 315.107 .783 .135 & $(32,24)$ \\
\hline Total & $\mathbf{1 0 . 3 9 5 . 3 1 8 . 7 3 4 . 7 5 5}$ & $\mathbf{2 9 8 , 5 5}$ & $\mathbf{2 . 4 5 9 . 3 3 5 . 3 3 0 . 0 8 1}$ & $\mathbf{1 8 5 , 3 8}$ \\
\hline Rata-rata & $\mathbf{1 . 0 3 9 . 5 3 1 . 8 7 3 . 4 7 5 , 5}$ & $\mathbf{2 9 , 8 6}$ & $\mathbf{2 4 5 . 9 3 3 . 5 3 3 . 0 0 8}$ & $\mathbf{1 8 , 5 4}$ \\
\hline Sumber: Bursa Efek Indonesia Tahun $2007-2016$ & & \\
\hline
\end{tabular}

Dari Tabel 2, dapat dilihat bahwa perkembangan hutang jangka panjang mengalami penurunan pada tahun 2011 sebesar $(59,44 \%)$ dan mengalami perkembangan tertinggi pada tahun 2012 sebesar 239,37\% dengan rata-rata perkembangan sebesar 29,86\%. Sedangkan pada laba bersih mengalami penurunan pada tahun 2016 sebesar $(32,24 \%)$ dan mengalami peningkatan paling tinggi pada tahun 2009 dengan perkembangan sebesar 103,15\%.

Dari fenomena tersebut penulis tertarik untuk melakukan penelitian ini dengan judul "Pengaruh Penggunaan Total Kas, Aktiva Tetap, dan Hutang Jangka Panjang Terhadap Perolehan Laba Bersih Pada PT. Adhi Karya Tbk Periode 2007-2016".

Adapun tujuan yang ingin dicapai dalam penelitian ini adalah:

1. Untuk mengetahui pengaruh penggunaan total kas, aktiva tetap, dan hutang jangka panjang terhadap perolehan laba bersih pada PT. Adhi Karya Tbk periode 2007-2016.

2. Untuk mengetahui pengaruh penggunakaan total kas, aktiva tetap, dan hutang jangka panjang terhadap perolehan laba bersih pada PT. Adhi Karya Tbk periode 2007-2016 secara simultan dan parsial.

\section{KAJIAN PUSTAKA \\ Konsep Manajemen}

Manajemen merupakan suatu proses kerja sama dengan dua orang atau lebih untuk mencapai tujuan organisasi dengan melakukan prencanaan, pengorganisasian, pengarahan, pengkoordinasian, dan pengendalian untuk mencapai tujuan organisasi efektif dan efisien dengan menggunakan sumber daya manusia dan sumber daya lainnya.

Berdasarkan pengertian manajemen yang telah dikemukakan sebelumnya, manajemen memiliki fungsi-fungsi sebagai berikut :

1. Perencanaan, Menunjukkan bahwa para manajer terlebih dahulu memikirkan tujuan dan kegiatannya.

2. Pengorganisasi, Para manajer mengkoordinasikan sumber daya manusia dan sumber daya bahan yang dimiliki organisasi.

3. Pengarahan, Pengarahan adalah proses untuk menumbuhkan semangat (motivation) para karyawan agar dapat bekerja keras dan giat serta membimbing mereka dalam melaksanakan rencana untuk mencapai tujuan yang efektif dan efisien.

4. Pengendalian, Bagian terakhir dari proses manajemen adalah pengendalian (cotrolling). Pengendalian yang dimaksudkan untuk melihat apakah kegiatan organisasi sudah sesuai dengan rencana sebelumnya. Fungsi pengendalian mencakup 
4 (empat) kegiatan, yakni : (1) menentukan standar prestasi, (2) mengukur prestasi yang telah dicapai, (3) membandingkan prestasi yang telah dicapai dengan standar prestasi dan, (4) melakukan perbaikan jika terdapat penyimpangan dari standar prestasi yang telah ditetapkan.

5. Pengawasan, Merupakan fungsi terakhir yang harus dilakukan dalam manajemen, sebab dengan pengawasan dapat diketahui hasil yang telah dicapai. Hal ini berarti bahwa dengan pengawasan akan dapat mengukur seberapa jauh hasil yang telah dicapai sesuai dengan yang direncanakan.

Tujuan Manajemen.

1. Melaksanakan dan mengevaluasi strategi yang kita pilih secara efektif dan efisien.

2. Memperbaharui strategi yang kita rumuskan agar sesuai dengan perkembangan lingkungan eksternal.

3. Melakukan peninjauan kembali terhadap kekuatan, kelemahan, peluang, dan ancaman peluang yang ada.

\section{Konsep Manajemen Keuangan}

Manajemen keuangan memiliki arti penting disemua jenis bisnis termasuk perbankan dan insitusi-institusi keuangan lainnya, sekaligus juga perusahaan-perusahaan industri dan retail.

1. Fungsi Manajemen Keuangan

a. Keputusan Investasi. Keputusan investasi adalah masalah bagaimana manajer keuangan harus mengalokasikan dana dalam bentuk-bentuk investasi yang akan dapat mendatangkan keuntungan dimasa yang akan datang.

b. Keputusan Pendanaan. Keputusan pendanaan ini sering disebut sebagai kebijakan struktur modal.

c. Keputusan Dividen. Dividen merupakan bagian keuntungan yang dibayarkan oleh perusahaan kepada para pemegang saham.

2. Tujuan Manajemen Keuangan

Ada bebarapa tujuan dari manajemen keuangan, yaitu :

a. Memaksimumkan nilai perusahaan.

b. Menjaga stabilitas finansial dalam keadaan yang selalu terkendali.

c. Memperkecil risiko perusahaan dimasa sekarang dan yang akan datang.

\section{Jenis Laporan Keuangan}

Ada bebarapa tujuan dari manajemen keuangan, yaitu :

1. Neraca

Neraca merupakan salah satu laporan keuangan yang terpenting bagi perusahaan.

2. Laporan Laba Rugi

Laporan laba rugi merupakan laporan yang menunjukkan jumlah pendapatan atau penghasilan yang diperoleh dan biaya-biaya yang dikeluarkan dan laba rugi dalam suatu periode tertentu (Kasmir, 2010:81).

3. Laporan Arus Kas

Menurut Fahmi (2014:23) Laporan arus kas memberikan informasi tentang arus kas masuk dan keluar dari kegiatan operasi, pendanaan, dan investasi selama periode akuntansi.

\section{Tujuan Laporan Keuangan}


1. Untuk memberikan informasi keuangan yang dapat dipercaya mengenai aktiva dan kewajiban serta modal suatu perusahaan.

2. Memberikan informasi tentang jenis, jumlah kewajiban, dan modal yang dimiliki perusahaan saat ini.

3. Memberikan informasi tentang jenis dan jumlah pendapatan yang diperoleh pada suatu periode tertentu.

4. Untuk memberikan infomasi penting lainnya mengenai perubahan dalam aktiva dan kewajiban suatu perusahaan, seperti informasi mengenai aktivitas pembiayaan dan investasi.

5. Memberikan informasi tentang kinerja manajemen perusahaan dalam suatu periode.

Kas

Baridwan (2009:71) Kas merupakan suatu alat pertukaran dan juga digunakan sebagai ukuran dalam akuntansi. Dalam neraca, kas merupakan aktiva yang paling lancar, dalam arti paling sering berubah.

\section{Aktiva Tetap}

Aktiva tetap merupakan harta atau kekayaan perusahaan yang digunakan dalam jangka panjang atau lebih dari satu tahun (Kasmir, 2010:77). Kemudian aktiva tetap dibagi menjadi dua yaitu aktiva tetap berwujud dan aktiva tetap tidak berwujud.

\section{Hutang Jangka Panjang}

Hutang tidak lancar atau hutang jangka panjang merupakan kewajiban perusahaan kepada pihak lain yang memiliki jangka waktu lebih dari satu tahun. Hutang jangka panjang meliputi : hutang obligasi, saham, hutang hipotik, utang dari lembaga keuangan, dan saham preferen.

\section{Laba}

Menurut Kasmir (2012:29, laba adalah selisih dari jumlah pendapatan yang lebih besar daru jumlah biaya. Keberhasilan suatu perusahaan dapat dilihat dari tingkat laba yang diperoleh perusahaan itu sendiri karena tujuan utama perusahaan adalah memperoleh laba yang sebesar-besarnya.

\section{Kerangka Pemikiran}

Salah satu yang berperan penting dalam mendukung lancarnya aktivitas perusahaan PT. Adhi Karya Tbk adalah tuntunan dengan melayani apa yang dibutuhkan masyarakat, memberi kemudahan, kepuasan, kenyamanan, yang berguna untuk mempertahankan dan menjamin kelangsungan usahanya dimasa yang akan datang.

Untuk mencapai tujuan yang diinginkan, maka perusahaan perlu melakukan analisis laporan keuangan yang terdiri dari neraca dan laba rugi. Laba adalah hal yang paling utama ditargetkan kenaikannya dalam setiap periode akuntansi dalam sebuah perusahaan, karena melalui inilah kinerja perusahaan dapat diukur kemampuannya dalam menjalankan perusahaan. Agar laporan keuangan yang disajikan dalam angka-angka dapat diartikan, perlu dilakukan analisis yang mendalam utnuk mengkaji, mengukur, dan memahami hal-hal yang tertulis dalam laporan.

\section{Hipotesis}


1. Diduga total kas, aktiva tetap, dan hutang jangka panjang berpengaruh signifikan terhadap laba bersih pada PT. Adhi Karya Tbk periode 2007-2016.

2. Diduga total kas, aktiva tetap, dan hutang jangka panjang secara simultan dan parsial berpengaruh signifikan terhadap laba bersih pada PT. Adhi Karya Tbk periode 20072016.

\section{METODE PENELITIAN}

\section{Jenis dan Sumber Data}

1. Data sekunder, Adalah data yang diperoleh melalui penelitian terdahulu yang dilakukan oleh pihak lain.

2. Sumber Data, Sumber data yang diperoleh untuk penelitian ini yaitu diperoleh dari situs idx Bursa Efek Indonesia.

\section{Metode Pengumpulan Data}

Metode pengumpulan data adalah alat bantu yang dipilih dan digunakan oleh peneliti dalam kegiatannya mengumpulkan data agar kegiatan tersebut menjadi sistematis dan dipermudah olehnya (Suharsimi Arikunto, 2010:265). Dalam penelitian ini metode pengumpulan data yang digunakan adalah Library Research (penelitian kepustakaan) yaitu merupakan suatu metode pengumpulan data yang digunakan untuk memperoleh data sekunder berupa berbagai teori-teori, konsep-konsep dan dari penelitian sebelumnya dengan menelaah berbagai literatur-literatur yang erat hubungannya dengan masalah yang diteliti.

\section{Metode Analisis Data}

1. Metode Kualitatif, Metode Kualitatif (Dyah dan Erwan Agus, 2017:20) adalah jenis data yang berupa kalimat /pernyataan bukan berupa angka.

2. Metode Kuantitatif, Metode kuantitatif (Dyah, Erwan Agus, 2017:21) adalah data yang berupa angka-angka.

\section{Alat Analisis}

1. Trend Horizontal

Analisa dengan mengadakan perbandingan laporan keuangan untuk beberapa periode atau beberapa saat sehingga akan diketahui perkembangannya (S. Munawir, 2007:36).

Rumus yang diguakan adalah sebagai berikut :

$$
T d=\frac{\text { Ta }- \text { Td }}{\text { Td }} \times 100
$$

Dimana :

$\mathrm{Ta}=$ Tahun yang dianalisa

$\mathrm{Td}=$ Tahun dasar

2. Regresi Linier Berganda

Model regresi sederhana hanya terdiri dari satu variabel dependen dan satu variabel independen, dengan rumus sebagai berikut:

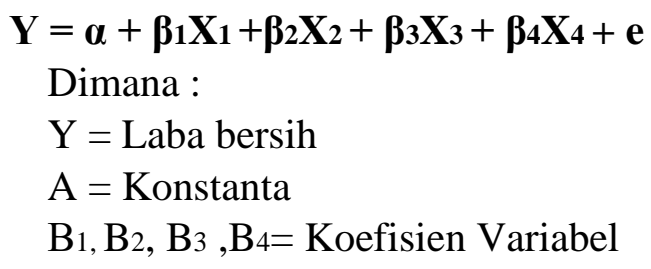




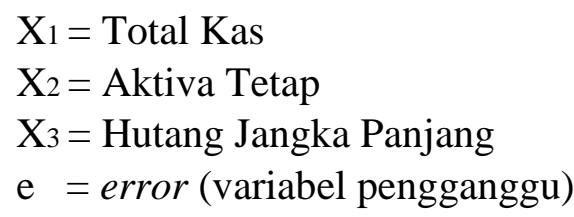

\section{Uji Asumsi Klasik}

1. Uji Normalitas, Uji normalitas bertujuan untuk menguji apakah dalam model regresi variabel dependen dan variabel independen mempunyai distribusi normal atau tidak.

2. Uji Autokorelasi, Uji autokorelasi bertujuan untuk menguji apakah model regresi linear ada korelasi antara kesalahan penganggu pada periode $t$ dengan kesalahan penganggu pada tabel t-1 (sebelumnya).

3. Uji Heterokedasitas, Uji heterokedasitas adalah untuk melihat ketidaksamaan varians dari residual satu pengamatan yang lain.

4. Uji Multikolinieritas, Uji multikolinieritas adalah uji untuk melihat ada tidaknya korelasi yang tinggi antar variabel-variabel bebas dalam suatu model regresi linier berganda

\section{Uji Hipotesis}

\section{Uji F}

Digunakan untuk menunjukkan apakah semua variabel independen yang dimasukkan dalam persamaan/ model regresi secara bersamaan berpengaruh terhadap variabel dependen. Uji F juga dapat dilihat dari output regresi yang dihasilkan oleh SPSS. Kita hendaknya merumuskan hipotesis nol untuk uji $\mathrm{F}$, yaitu :

$>$ Ho : $\beta=0$, artinya semua variabel independen bukan merupakan penjelas variabel dependen.

$>$ Ho : $\beta \neq 0$, artinya semua variabel independen secara simultan merupakan penjelas yang signifikan terhadap variabel dependen.

Jika uji $\mathrm{f}>4$ maka Ho ditolak dan Ha diterima.Semua variabel independen yang dimasukkan dalam persamaan/ model regresi secara bersamaan berpengaruh terhadap variabel dependen.

\section{Uji t}

Merupakan uji signifikan parameter individual. Uji t menunjukkan seberapa jauh pengaruh variabel independen secara individual terhadap variabel dependennya.

\section{Koefisien Determinasi}

Koefisien determinasi sering disimbolkan dengan " $\mathrm{R}$ " " pada prinsipnya mengukur seberapa besar kemampuan model menjelaskan variasi variabel dependen.

\section{Operasional Variabel}


Operasional variabel merupakan devinisi atau uraian-uraian yang menjelaskan dari suatu variabel-variabel yang akan diteiliti dan mencakup indikator-indikator yang ada pada masing-masing variabel.

\section{HASIL DAN PEMBAHASAN}

\section{Hasil Penelitian}

Persamaan regresi linier berganda digunakan untuk menjelaskan pengaruh signifikan total kas, aktiva tetap, dan hutang jangka panjang terhadap laba bersih yang bertujuan untuk mengujji hipotesis yang diajukan penulis.

Persamaan regresi linier berganda sebagai berikut :

$$
\begin{aligned}
\mathrm{Y}= & \boldsymbol{\alpha}+\boldsymbol{\beta 1 X 1}+\boldsymbol{\beta 2 X} \mathbf{2}+\boldsymbol{\beta 3 X 3}+\boldsymbol{\beta 4 X} \mathbf{4}+\mathbf{e} \\
& 68244,954+0,29 \mathrm{X} 1+(-0,79) \mathrm{X} 2+0,167 \mathrm{X} 3+\mathrm{e} \\
& 68244,954+0,29 \mathrm{X} 1-0,79 \mathrm{X} 2+0,167 \mathrm{X} 3+\mathrm{e}
\end{aligned}
$$

Keterangan :

$\mathrm{Y}=$ Laba Bersih

b = Koefisien Regresi

a $=$ Konstanta

$\mathrm{X} 1=$ Total Kas

$\mathrm{X} 2$ = Aktiva Tetap

X3 = Hutang Jangka Panjang

e $=$ Tingrkat Kesalahan

Dari persamaan regresi linier diatas, maka dapat dianalisa sebagai berikut:

Koefisien regresi Total Kas $\left(\mathrm{X}_{1}\right)$ adalah sebesar 0,29. Nilai koefisien positif menunjukkan bahwa total aktiva lancar berpengaruh positif terhadap laba bersih dari perusahaan PT. Adhi Karya Tbk periode 2007-2016 artinya terjadi hubungan positif antara variabel $\mathrm{X}_{1}$ dengan $\mathrm{Y}$, maka semakin naik variabel $\left(\mathrm{X}_{1}\right)$ akan semakin naik variabel (Y). Apabila mengalami kenaikan sebesar 1\% maka pengaruh terhadap laba bersih akan naik sebesar 0,29\%.

$>$ Koefisien regresi Total Aktiva Tetap $\left(\mathrm{X}_{2}\right)$ adalah sebesar -0,79. Nilai koefisien negatifmenunjukkan bahwa total aktiva tetap berpengaruh negatifterhadap laba bersih dari perusahaan PT. Adhi Karya Tbk periode 2007-2016 artinya terjadi hubungan negatif antara variabel $\mathrm{X}_{2}$ dengan $\mathrm{Y}$, maka semakin naik variabel $\left(\mathrm{X}_{2}\right)$ akan semakin menurun variabel (Y). Apabila mengalami kenaikan sebesar $1 \%$ maka pengaruh terhadap laba bersih akan menurun sebesar $-0,79 \%$.

> Koefisien regresi Hutang Jangka Panjang $\left(\mathrm{X}_{3}\right)$ adalah sebesar 0,167. Nilai koefisien positif menunjukkan bahwa total hutang berpengaruh positif terhadap laba bersih dari perusahaan PT. Adhi Karya Tbk periode 2007-2016 artinya terjadi hubungan positif antara variabel $\mathrm{X}_{3}$ dengan $\mathrm{Y}$, maka semakin naik variabel $\left(\mathrm{X}_{3}\right)$ akan semakin naik variabel (Y). Apabila mengalami kenaikan sebesar $1 \%$ maka pengaruh terhadap laba bersih akan naik sebesar $0,167 \%$.

Koefisien regresi Modal $\left(\mathrm{X}_{4}\right)$ adalah sebesar 0,133. Nilai koefisien positif menunjukkan bahwa modal berpengaruh positif terhadap laba bersih dari perusahaan PT. Adhi Karya Tbk periode 2007-2016 artinya terjadi hubungan positif antara variabel $\mathrm{X}_{4}$ dengan $\mathrm{Y}$, maka semakin naik variabel $\left(\mathrm{X}_{4}\right)$ akan semakin naik variabel $(\mathrm{Y})$. Nilai regresi variabel modal 
sebesar 0,133 apabila mengalami kenaikan sebesar $1 \%$ maka pengaruh terhadap laba bersih akan naik sebesar $0,133 \%$.

\section{Hasil Uji Asumsi Klasik \\ Uji Normalitas}

Dasar pengambilan keputusan dari analisis normal probability plot, yakni : (1). Jika data menyebar disekitar garisdiagonal dan mengikuti arah garis diagonal menunjukkan pola distribusi normal, maka model regresi memenuhi asumsi normal. (2). Jika data menyebar jauh dari garis diagonal dan tidak mengikuti arah garis diagonal maka tidak menunjukkan pola distribusi normal, maka model regresi memenuhi asumsi normalitas. Dari garis histogram dan normal probability plot pada gambar diatas terlihat bahwa grafik P-P plot diatas memperlihatkan titik menyebar disekitar arah garis yang menunjukkan pola distribusi normal.

\section{Uji Autokorelasi}

Uji autokorelasi adalah uji untuk melihat apakah terjadi korelasi antara suatu periode $\mathrm{t}$ dengan t-1.Cara yang digunakan untuk mendeteksi ada atau tidaknya autokorelasi adalah dengan menggunakan uji Durbin-Waston (DW test). Pendeteksian ada atau tidaknya gejala autokorelasi adalah jika angka DW dibawah -2 berarti ada autokorelasi negatif, sedangkan angka DW -2 sampai 2 berarti tidak ada autokorelasi, dan jika angka DW diatas +2 , berarti autokorelasi positif.

\section{Uji Heterokedasitas}

Dari uji heterokedasitas yakni : (1). Jika ada pola tertentu , yang teratur (bergelombang, melebar, kemudian menyempit), maka mengindikasikan telah terjadi heterokedasitas. (2). Jika ada dibawah angka nol pada sumbu Y, maka mengindikasi tidak terjadi heterokedasitas.

\section{Uji Multikolinieritas}

Uji multikolinieritas bertujuan untuk menguji apakah dalam model regresi ditemukan adanya korelasi yang tinggi atau sempurna antar variabel bebas yaitu total aktiva lancar, aktiva tetap, hutang, dan modal yang saling berhubungan secara linear. Untuk mengetauhi apakah terjadi multikolinieritas dalam suatu model regresi dapat dilihat pada dari nilai VIF (Variance Inflation Factor).Apabila nilai tolerance $<0,1$ dan VIF $>10$, maka terdapat masalah multikolinieritas pada variabel tersebut.

\section{Hasil Uji Hipotesis}

\section{a. Uji F}

Berdasarkan hasil output SPSS 22 menunjukkan bahwa ada pengaruh signifikan secara bersama-sama dari ketiga variabel independen (Total kas, aktiva tetap, dan hutang jangka panjang) terhadap laba bersih.

Dapat diketahui bahwa secara bersama-sama variabel independen memiliki pengaruh terhadap variabel dependen. Hal ini terlihat dari F hitung sebesar 15,327 dengan signifikan sebesar 0,003. Berdasarkan kriteria pengujian hipotesis, jika $F$ hitung $>F$ tabel maka $\mathrm{H}_{\mathrm{o}}$ ditolak dan $\mathrm{H}_{\mathrm{a}}$ diterima dan jika $\mathrm{F}$ hitung < $\mathrm{F}$ tabel maka Ho diterima dan Haditolak, Fsig $<0,05$ maka $\mathrm{H}_{\mathrm{o}}$ dan $\mathrm{H}_{\mathrm{a}}$ diterima. Dengan menggunakan tingkat keyakinan $95 \% \alpha=0,05, d f$ 
$=n-k-1 ; 10-3-1=6$ (n adalah adalah jumlah data dan $\mathrm{k}$ adalah jumlah variabel independen), maka diperoleh nilai $\mathrm{F}$ tabel sebesar 4,76. Dari hasil pengujian terlihat bahwa nilai $\mathrm{F}$ hitung sebesar 15,327> 4,76 dengan nilai signifikan 0,003 < 0,05, maka dapat dikatakan bahwa semua variabel $\mathrm{X}$ (total kas, aktiva tetap, dan hutang jangka panjang) secara simultan bersama-sama berpengaruh terhadap variabel Y (laba bersih).

\section{b. Uji t}

Hipotesis dalam penelitian ini akan diuji dengan uji t. Uji t bertujuan untuk mengetahui apakah variabel independen berpengaruh secara parsial terhadap variabel dependen pada perusahaan PT. Adhi Karya Tbk. Jika t hitung $>\mathrm{t}$ tabel maka Ho ditolak dan $\mathrm{H}_{\mathrm{a}}$ diterima dengan tingkat signifikan adalah 0,025.

\section{c. Koefisien Determinasi $\left(\mathbf{R}^{2}\right)$}

Koefisien Determinasi $\left(\mathrm{R}^{2}\right)$ pada intinya mengukur seberapa jauh kemampuan model dalam menerangkan variasi variabel dependen. Koefisien korelasi antara Total Kas, Aktiva Tetap, dan Hutang Jangka Panjang terhadap Laba Bersih pada PT. Adhi Karya Tbk periode 2007-2016 adalah 0,941, artinya terdapat hubungan yang erat antara variabel total kas, aktiva tetap, dan hutang jangka panjang terhadap laba bersih pada PT. Adhi Karya Tbk Periode 2007-2016. Dari hasil pengujian korelasi maka diperoleh $R$ Square sebesar 0,885 yang berarti menunjukkan bahwa besarnya kontribusi $\mathrm{X}_{1}, \mathrm{X}_{2}$, dan $\mathrm{X}_{3}$ terhadap $\mathrm{Y}$ adalah $88,5 \%$ dan selebihnya dipengaruhi oleh faktor lain sebesar $11,5 \%$.

\section{Pembahasan}

\section{Pengaruh Penggunaan Total Kas, Aktiva Tetap, dan Hutang Jangka Panjang} Terhadap Perolehan Laba Bersih Periode 2007-2016.

Berdasarkan hasil Regresi Linier Berganda dapat disimpulkan bahwa total kas berpengaruh positif terhadap laba bersih dari perusahaan PT. Adhi Karya Tbk periode 20072016 artinya terjadi hubungan positif antara variabel X1 (Total Aktiva Lancar) dengan Y (Laba Bersih). Sedangkan pada aktiva tetap terdapat pengaruh negatif terhadap laba bersih dari perusahaan PT. Adhi Karya Tbk Periode 2007-2016 artinya terjadi hubungan negatif antara X2 (Total Aktiva Tetap) dengan Y (Laba Bersih). Pada total hutang terdapat pengaruh positif pada laba bersih dari perusahaan PT. Adhi Karya Tbk Periode 2007-2016 artinya terjadi hubungan positif antara X3 (Total Hutang) dengan Y (Laba Bersih).

2. Pengaruh Penggunaan Total Kas, Aktiva Tetap, dan Hutang Jangka Panjang Terhadap Perolehan Laba Bersih Pada PT. Adhi Karya Tbk Periode 2007-2016 secara Simultan dan Parsial.

a) Secara Simultan

Berdasarkan hasil uji secara simultan (Uji F), dapat disimpulkan bahwa nilai $\mathrm{F}$ hitung $>\mathrm{F}$ tabel yaitu sebesar 15,327 > 4,76 dengan tingkat signifikan 0,003 hal ini menunjukkan total kas, aktiva tetap, dan hutang jangka panjang terdapat pengaruh yang signifikan terhadap laba bersih secara simultan pada PT. Adhi Karya Tbk Periode 2007-2016.

b) Secara parsial 


\section{Total Kas}

Berdasarkan hasil uji secara parsial (Uji t), dapat disimpulkan bahwa total kas tidak berpengaruh secara parsial terhadap laba bersih pada PT. Adhi Karya Tbk.

2. Berdasarkan hasil uji secara parsial (Uji t), dapat disimpulkan bahwa aktiva tetap tidak berpengaruh secara parsial terhadap laba bersih pada PT. Adhi Karya Tbk.

3. Berdasarkan hasil uji secara parsial (Uji t), dapat disimpulkan bahwa hutang jangka panjang berpengaruh secara parsial terhadap laba bersih pada PT. Adhi Karya Tbk

\section{KESIMPULAN DAN SARAN}

\section{Kesimpulan}

Berdasarkan hasil penelitian dan pembahasan, maka dapat ditarik kesimpulan sebagai berikut :

1. Adanya pengaruh positif antara total kas (X1) dengan laba bersih (Y) dan hutang jangka panjang (X3) dengan laba bersih (Y) pada PT. Adhi Karya Tbk, maka semakin naik variabel (X1, dan X3) akan semakin naik variabel (Y). Sedangkan pada aktiva tetap (X2) terdapat pengaruh negatif dengan laba bersih (Y) pada PT. Adhi Karya Tbk periode 20072016, maka semakin naik variabel (X2) akan semakin menurun variabel (Y).

2. Pengaruh Penggunaan Total Kas, Aktiva tetap, dan Hutang Jangka Panjang Secara Simultan dan Parsial Terhadap Laba Bersih.

Berdasarkan hasil penelitian secara simultan bahwa variabel independen (total kas, aktiva tetap, dan hutang jangka panjang) berpengaruh terhadap variabel dependen (laba bersih). Hasil ini ditunjukkan dengan nilai $\mathrm{F}$ hitung $>\mathrm{F}$ tabel atau 15,327 > 4,76 dengan nilai signifikan $0,003<0,05$. Sedangkan hasil penelitian secara parsial menunjukkan bahwa total kas (X1) tidak berpengaruh siginifikan terhadap laba bersih (Y) pada PT. Adhi Karya (Tbk) periode 2007-2016. Pada aktiva tetap (X2) secara parsial tidak berpengaruh signifikan terhadap laba bersih (Y) pada PT. Adhi Karya (Tbk) periode 2007-2016. Dan pada hutang jangka panjang (X3) secara parsial berpengaruh signifikan terhadap laba bersih (Y) pada PT. Adhi Karya (Tbk) periode 2007-2016.

\section{Saran}

Dari kesimpulan yang dapat diambil, dalam kesempatan ini penulis dapat memberikan saran sebagi berikut :

1. Bagi peneliti selanjutnya perlu memilih perusahaan dibidang lain untuk memperoleh hasil yang lebih valid guna mempertinggi daya uji empiris tentang total aktiva lancar, aktiva tetap, hutang dan modal terhadap laba bersih.

2. Bagi perusahaan PT. Adhi Karya (Tbk) sangat penting untuk menentukan metode penyusutan terhadap aktiva tetap, karena biaya penyusutan merupakan alokasi biaya yang mempengaruhi besarnya tingkat laba perusahaan dalam laporan keuangan. Akumulasi penyusutan tidak boleh lebih besar dari nilai aset supaya perusahaan melakukan permajanpermajan terhadap aktiva tetap.

\section{DAFTAR RUJUKAN}

Adisetiawan, R, 2012. Analisis Pengaruh Kinerja Keuangan Dalam Memprediksi Laba. Fakultas Ekonomi, Universitas Baanghari, Vol. 10, No. 3.. 
Agus Indriyo, Gitosudarmo dan Basri. 2008. Manajemen Keuangan. Yogyakarta: BPFE.

Arikunto, Suharsimi, 2010. Prosedur Penelitian Suatu Pendekatan Praktek, Jakarta : Penerbit Rineka Cipta.

Baridwan, Zaki, 2009. Sisrem Akuntansi Penyusutan Prosedur dan Metode. Yogyakarta YKPN.

Dewi, Desilia Purnama.2012. Analisis Hutang Jangka Panjang, Hutang Jangka Pendek dan Modal Kerja Bersih Terhadap Laba pada PT. Griya Asri prima. Skripsi.

Diana, Ayu Putri. 2016. Pengaruh Perputaran Kas, Piutang, Persediaan Terhadap Profitabilitas pada Perusahaan Semen di BEI. Jurnal Ilmu dan Riset Manajemen: Volume 5, Nomor 3, Maret.

Dyah dan Erwan Agus, 2017. Metode Penelitian Kuantitatif, Edisi Kedua : Grava Media.

Darmawan, Putra Dwi, 2013. Pengaruh Aktiva Tetap, Hutang jangka Panjang,dan Modal terhadap Laba Bersih Perusahaan Agribisnis Indeks LQ 45 yang Terdaftar di Bursa Efek Indonesia. Jurnal Manajemen Agribisnis. Vol.1, No.2.

Efendi, Usman, 2014. Asas Manajemen. Jakarta: Rajawali Pers.

Fuad, M. Dkk, 2009. Pengantar Bisnis, Jakarta : Gramedia Pustaka Utama.

Fahmi, Irham. 2013. Analisis Laporan Keuangan, Alfabeta, Bandung.

---------, 2014. Pengantar Manajemen Keuangan. Bandung : Alfabeta.

Harahap, Sofyan Syafitri, 2007. Teori Akuntansi, Jakarta PT. Raja Grafindo Persada.

Hendra Setiawan dan Marwan Effendy, 2009. Pengaruh Likuiditas dan Hutang Jangka PanjangTerhadap Kemapulaban: Studi Kasus Pada PT. Matahari Putra Prima, Tbk dan PT. Ramayana Lestari Sentosa Tbk. Jurnal Ilmiah Kesatuan No. 1 Volume 11, Januari 2009.

Kasmir. (2010). Pengantar Manajemen Keuangan. Jakarta: Kencana Prenada Media Group.

------, 2014. Analisis Laporan Keuangan. PT. Raja Grafindo: Jakarta

Lyn M Fraser dan Aileen Ormiston, 2008. Memahami Laporan Keuangan, Edisi Ketujuh, Indeks. Jakarta (Terjemahan).

Manullang M. 2005. Dasar-dasar Manajemen. Yogyakarta : Gajah Mada University.

Martono dan Harjito. 2010. Manajemen Keuangan (Edisi 3). Yogyakarta: Ekonisia.

Nafarin, M. 2013. Penganggaran Perusahaan. Edisi 3. Salemba Empat.

Nina dan Ni Ketut Purwanti. 2013. Pengaruh Perputaran Kas, Perputaran Piutang dan Perputaran Utang Terhadap Laba Bersih di Food and Beferages. Jurnal.

Riyanto, Bambang, 2001. Dasar-dasar Pembelanjaan Perusahaan, Edisi 9. Yogyakarta: BFPE.

2008. Dasar-dasar Pembelanjaan Perusahaan, Edisi 4. Yogyakarta: BFPE.

S. Munawir, 2007. Analisis Laporan Keuangan Liberty. Jakarta.

Sunjoyo, dkk. 2013. Aplikasi SPSS Untuk Smart Riset. ALFABETA. Bandung.

Sutrisno, 2009. Manajemen Keuangan. Yogyakarta : Ekonisia.

Sumarso, 2004. Akuntansi Sebagai Pengantar, Salemba Empat: Jakarta 